\title{
ANALISIS KAPASITAS PRODUKSI TELUR AYAM DAN EFISIENSI PEMBERIAN INPUT PADA PERUSAHAAN UD. FITRA ABADI
}

\author{
Adolf B. Heatubun*, Michael J. Matatula, dan Marcus Veerman \\ Jurusan Peternakan Fakultas Pertanian, Universitas Pattimura \\ Jln. Ir. M. Putuhena, Kampus Poka, Ambon 97233 \\ ${ }^{*}$ Email : adolf_bas@yahoo.com
}

\begin{abstract}
ABSTRAK
Kegiatan produksi telur membutuhkan kemampuan peternak atau manajer perusahaan peternakan untuk mengendalikan jumlah produksi yang dihasilkan, karena merupakan fungsi dari input yang digunakan. Masingmasing jenis input memiliki kapasitas tertentu yang disumbangkan pada tingkat produksi. Ketidaktepatan mengendalikan fungsi produksi dapat menyebabkan tingkat produksi tidak maksimal, penggunaan jumlah input tidak optimal dan tidak efisien. Penelitian ini bertujuan menganalisis kapasitas produksi telur yang dihasilkan terkait penggunaan input-input makanan ternak. Penelitian dilakukan pada perusahaan peternakan ayam petelur UD. Fitra Abadi, dan data dikumpulkan selama bulan Oktober 2018. Sampel yang digunakan adalah satu blok kandang dengan jumlah induk ayam petelur 2.100 ekor. Hasil penelitian menunjukkan kapasitas ayam petelur sebagai input tetap masih rendah yaitu produksi hanya sebesar 26,19\%. Ransum jadi, pakan jagung, dan pakan dedak berhubungan positif dengan produksi telur. Namun secara statistik hanya ransum jadi yang signifikan mempengaruhi produksi telur, sedangkan kedua pakan lainnya tidak signifikan. Kapasitas dari ketiga input yang digunakan lebih kecil dari satu (bersifat inelastis), namun kapasitas input ransum jadi lebih besar dari kedua jenis pakan lainnya. Perusahaan perlu mengurangi pemberian pakan jagung dan dedak dan lebih mengutamakan pemberian penuh ransum jadi untuk memperoleh jumlah produksi yang maksimal.
\end{abstract}

Kata kunci: Kapasitas produksi, input ransum jadi, pakan jagung, pakan dedak, regresi berganda

\section{ANALYSIS OF CHICKEN EGG PRODUCTION CAPACITY AND INPUT EFFICIENCY IN THE COMPANY OF UD. FITRA ABADI}

\begin{abstract}
Egg production activities require the ability of Farmers or Farm company managers to control the amount of production produced, given the amount of production produced is a function of the inputs used. Each type of input has a certain capacity that is contributed at the level of production. Inaccuracy in controlling the production function can cause the production level to be not optimal, the use of the number of inputs is not optimal and inefficient. This study aims to analyze the egg production capacity produced related to the use of animal feed inputs. The study was conducted at the laying hens company UD. Fitra Abadi, and data were collected during October 2018. The sample used was one cage block with 2,100 hens laying hens. The results showed the capacity of laying hens as a permanent input was still low, namely production is only $26.19 \%$. The shop food, corn feed, and bran feed are positively related to egg production. But statistically only shop food that significantly affect egg production, while the other two feeds are not significant. The capacity of the three inputs used is smaller than one (inelastic), but the capacity of shop food is greater than the other two feeds. The company needs to reduce the feeding of corn and bran and to prioritize giving full shop food to get the maximum amount of production.
\end{abstract}

Key words: Production capacity, shop food, corn feed, bran feed, multiple regression

\section{PENDAHULUAN}

Ketika peternak dan manajer pada perusahaan peternakan memasuki kegiatan produksi, mereka akan bekerja dalam sebuah sistem fungsi produksi yakni hubungan antara jumlah output yang dihasilkan dan jumlah input yang digunakan. Dalam penggunaan input yang bersifat kombinasi, masing-masing input memiliki produktivitas tertentu yang dapat disumbangkan pada level produksi yang dicapai. Mishra (2007) mendefinisikan fungsi produksi sebagai hubungan antara output maksimal yang layak secara teknis dan 
Heatubun dkk. 2020: Analisis Kapasitas Produksi Telur Ayam....

input yang diperlukan untuk menghasilkan output tersebut. Ini menunjukkan jumlah input yang disetting untuk digunakan merupakan jumlah optimal yang digunakan unuk menghasilkan tingkat output yang layak secara teknis. Secara aljabar formulasi hubungan antara output dan input-input adalah sebagai berikut: $P$ $=f\left(x_{1}, x_{2}, x_{3}\right)$, di mana $\mathrm{P}$ adalah produksi, $\mathrm{x}_{1}-\mathrm{x}_{3}$ adalah jenis input produksi.

Sebagai peternak dan manajer apakah mereka mengetahui konsekuensi dari mengetahui secara tepat pengukuran kapasitas input yang digunakan terhadap produksi yang dihasilkan dan konsekuensi lanjutan terhadap usaha bisnis yang dijalankan ke depan? Umumnya orang menganggap mereka adalah professional dan tidak ada yang meragukan kemampuannya. Tapi fakta lapangan dapat mununjukkan keadaan sebaliknya. Yadav dan Marwah (2015) memberikan definisi tentang produktivitas adalah ukuran rata-rata dari efisiensi produksi. Ini dapat dinyatakan sebagai rasio output terhadap input yang digunakan dalam proses produksi, yaitu output per unit input. Ketika semua output dan input dimasukkan dalam ukuran produktivitas disebut produktivitas total.

Syverson (2011) juga menyatakan produktivitas biasanya didefinisikan sebagai rasio antara volume output dan volume input. Dengan kata lain, ini mengukur seberapa efisien input produksi, seperti tenaga kerja dan modal, digunakan dalam ekonomi untuk menghasilkan tingkat output tertentu. Produktivitas dianggap sebagai sumber utama pertumbuhan ekonomi dan daya saing. Selanjutnya Paul (2019) mendefinisikan istilah "produktivitas marjinal" mengacu pada output tambahan yang diperoleh dengan menambahkan satu unit input misalnya tenaga kerja; semua input lainnya dijaga konstan. Jadi, teknologi dan efisiensi pabrik tetap sama. Sebagai contoh, produktivitas marjinal adalah tambahan jeans yang dijahitkan, yaitu output yang diperoleh, dengan mempekerjakan satu pekerja tambahan.

Setiap input memiliki produktivitas marginal dengan tingkat berbeda terhadap output. Indikator ini menunjukkan kapasitas input bersangkutan dalam menunjang ouput. Makin tinggi produktivitas marginal dari masing-masing input diharapkan produksi makin tinggi. Penelitian ini bertujuan menganalisis kapasitas produksi telur yang dihasilkan terkait penggunaan input-input makanan ternak pada perusahan UD Fitra Abadi.

\section{BAHAN DAN METODE}

Penelitian ini dilaksanakan pada Perusahaan Ayam Petelur UD. Fitra Abadi di Kecamatan Leihitu, Kabupaten Maluku Tengah, Provinsi Maluku menggunakan metode survei. Lokasi penelitian dipilih secara purposive yaitu sesuai dengan tujuan penelitian yang ingin dicapai dan keberadaan perusahaan ayam petelur yang tersedia. Penelitian berlangsung selama satu bulan (31 hari) pada bulan Oktober 2018.

Data dikumpukan atas data primer. Data primer dicatat dan diukur setiap hari selama penelitian berlangsung mencakup jumlah produksi telur, pengukuran jumlah pakan yang diberikan (ditimbang). Penelitian ini mengambil sampel pada satu blok kandang dengan ukuran usaha induk ayam petelur sebanyak 2.100 ekor. Untuk ketelitian, makanan ditimbang sebelum diberikan dan juga ditimbang bagian makanan tersisa sebelum diberikan jumlah yang baru di hari berikutnya.

Data yang dikumpulkan dianalisis dengan menggunakan regresi linear berganda dengan persamaan sebagai berikut :

$$
\mathrm{Q}=\mathrm{a}+\mathrm{bRsJd}+\mathrm{cPkJgg}+\mathrm{dPkDdk}+\mathrm{e} \ldots(1)
$$

keterangan :

$\mathrm{Q}=$ Jumlah produksi telur (butir)

RsJd = Jumlah ransum jadi $(\mathrm{kg})$

PkJgg = Jumlah pakan jagung $(\mathrm{kg})$

PkDdk = Jumlah pakan dedak $(\mathrm{kg})$

$\mathrm{a}=$ Parameter intersep

$\mathrm{b}, \mathrm{c}, \mathrm{d}=$ Nilai parameter masing-masing variabel input.

Hipotesis penelitian dirumuskan sebagai: (1) makin tinggi jumlah ransum jadi yang diberikan, makin banyak jumlah telur yang dihasilkan (hubungan positif) ; (2) makin tinggi jumlah pakan jagung yang diberikan, makin banyak jumlah telur yang dihasilkan (hubungan positif); dan (3) makin tinggi jumlah pakan dedak yang diberikan, makin banyak jumlah telur yang dihasilkan (hubungan positif).

\section{HASIL DAN PEMBAHASAN}

\section{Hasil Analisis Regresi Berganda}

Analisis regresi bertujuan mengetahui pengaruh variabel-variabel independen terhadap variabel dependen. Diharapkan agar hasil analisis regresi cukup akurat sehingga dapat digunakan untuk menjelaskan perilaku riil dari keadaan yang diselidiki. Konsep statistik menetapkan bahwa hasil analisis regresi akan valid jika memenuhi ketentuan yang disebut sebagai "asumsi klasik". Jika asumsi ini dilanggar maka hasil analisis regresi akan bias yang berarti hasil analisis tersebut tidak dapat menjelaskan dengan benar fakta yang sesungguhnya (Gujarati dan Poter, 2010). Dengan perkataan lain, hasil analisis tidak akurat menjelaskan fakta nyata.

Sesuai penjelasan diatas, perlu dilakukan uji asumsi klasik terlebih dahulu sebelum analisis regresi dilakukan. Uji asumsi klasik diantaranya meliputi uji normalitas dan uji multikolinearitas (Latan dan Selva, 2013).

Uji normalitas bertujuan untuk mengetahui apakah residual data dari model regresi linear memiliki 
distribusi normal atau tidak. Model regresi yang baik adalah yang residual datanya berdistribusi normal.

Terdapat dua cara untuk mendeteksi apakah residual data berdistribusi normal atau tidak yaitu dengan melihat grafik normal probability plot dan uji statistik One-Sample Kolmogorov-Smirnov Test. Apabila pada grafik normal probability plot tampak titik-titik menyebar berhimpit di sekitar garis diagonal dan searah mengikuti garis diagonal maka dapat disimpulkan residual data memiliki distribusi normal atau memenuhi asumsi klasik normalitas. Untuk uji statistik One-Sample Kolmogorov-Smirnov Test jika diperoleh nilai signifikansi $>0,05$ maka dapat disimpulkan residual data terdistribusi normal (Latan dan Selva, 2013).

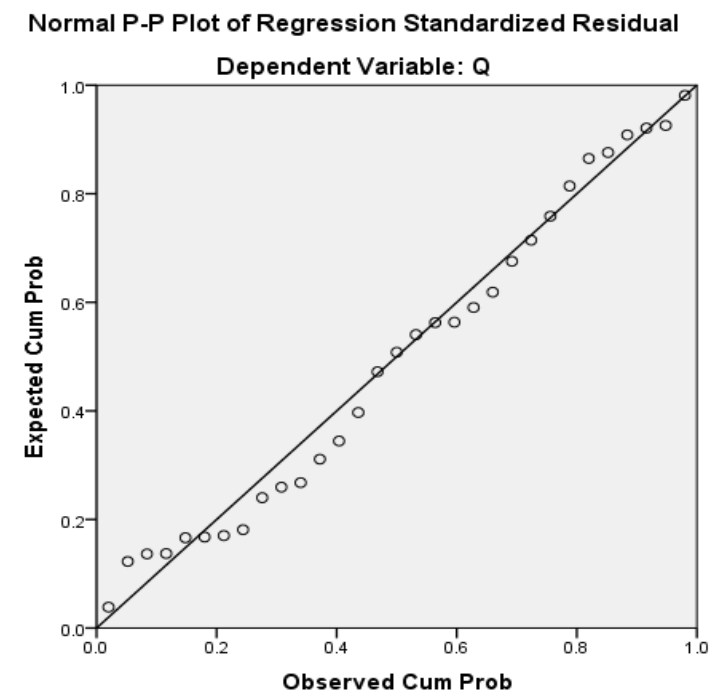

Gambar 1. Diagram Normalitas Data

Sumber : Hasil print out komputer

Gambar 1 menunjukkan titik-titik plot relatif berhimpitan dengan garis diagonal sehingga dapat disimpulkan bahwa data terdistribusi normal atau memenuhi asumsi klasik. Tabel 1 menyajikan hasil uji statistik One-Sample Kolmogorov-Smirnov Test yang menunjukan nilai Asymp. Sig. (2-tailed) sebesar 0,200 dimana $>0,05$ sehingga dapat disimpulkan bahwa data terdistribusi normal.

Tabel 1. Hasil Uji Normalitas Data KolmogorovSmirnov

\begin{tabular}{llr}
\hline & & $\begin{array}{c}\text { Unstandardized } \\
\text { Residual }\end{array}$ \\
\hline $\mathrm{N}$ & & 31 \\
\hline $\begin{array}{l}\text { Normal } \\
\text { Parameters }\end{array}$ & Mean & 0,0000000 \\
\cline { 2 - 3 } & Std. Deviation & 37,93886 \\
\hline Most Extreme & Absolute & 0,098 \\
\cline { 2 - 3 } Differences & Positive & 0,098 \\
\cline { 2 - 3 } & Negative & $-0,078$ \\
\hline Test Statistic & & 0,098 \\
\hline Asymp. Sig. (2-tailed) & $0,200^{\mathrm{c}, \mathrm{d}}$ \\
\hline
\end{tabular}

Uji multikolinearitas bertujuan untuk mengetahui apakah ada atau tidak korelasi antar variabel independen dalam model regresi. Bila terdapat korelasi maka menghasilkan parameter dugaan yang bukan hasil estimasi terbaik (BLUE = Best Linear Unbiased Estimates) (Supranto, 2001).

Cara mendeteksi ada tidaknya multikolinearitas pada model regresi adalah dengan melihat nilai Telorance dan VIF (Variance Inflation Factor). Nilai yang direkomenda-sikan adalah nilai Telorance harus > 0.10 dan nilai VIF < 10 (Hair, et al., 2010 dalam Latan dan Selva, 2013). Hasil uji multikolinearitas ditunjukkan pada Tabel 2 berikut ini.

Tabel 2. Hasil Uji Multikolinearitas

\begin{tabular}{|c|c|c|c|}
\hline \multicolumn{4}{|c|}{ Coefficients } \\
\hline & \multirow{2}{*}{ Model } & \multicolumn{2}{|c|}{ Collinearity Statistics } \\
\hline & & Tolerance & VIF \\
\hline \multirow{3}{*}{1} & Ransum jadi & 0,760 & 1,300 \\
\hline & Pakan jagung & 0,950 & 1,035 \\
\hline & Pakan dedak & 0,764 & 1,310 \\
\hline
\end{tabular}

Hasil uji multikolinearitas pada tabel di atas, nilai Telorance ketiga variabel independen ransum, pakan jagung, dan pakan dedak semuanya $>0,10$. Juga nilai VIF ketiga variabel $<10$ maka dapat disimpulkan tidak terdapat multikolinearitas di antara variabel 
Heatubun dkk. 2020: Analisis Kapasitas Produksi Telur Ayam....

independen dan hasil ini memenuhi asumsi klasik multikolinearitas.
Hasil analisis regresi berganda seperti ditunjukkan pada Tabel 3, 4, dan Tabel 5.

Tabel 3. Nilai Statistik Koefisien Determinasi $\left(\mathrm{R}^{2}\right)$

\begin{tabular}{ccccc}
\hline \multicolumn{4}{c}{ Model Summary } \\
\hline Model & $\mathrm{R}$ & $\mathrm{R}^{2}$ & Adjusted R & Std. Error \\
\hline 1 & $0,932^{\mathrm{a}}$ & 0,868 & 0,853 & 39,991 \\
\hline a. Predictors: (Constant), RsJd, PkJgg, PkDdk & & \\
\hline
\end{tabular}

Tabel 4. Nilai Statistik Uji F

\begin{tabular}{lrrrrc}
\hline \multicolumn{1}{c}{ Model } & Sum of Squares & Df & Mean Square & F & Sig. \\
\hline Regression & 2484136,838 & 3 & 94712,279 & 59,222 & $0,0001^{\text {b }}$ \\
Residual & 43180,711 & 27 & 1599,286 & & \\
Total & 327317,548 & 30 & & & \\
\hline a. Dependent Variable: Q & & & & \\
b. Predictors: (Constant), RsJd, PkJgg, PkDdk & & & & \\
\hline
\end{tabular}

Tabel 5. Nilai Statistik Parameter Estimasi dan Uji $t$

\begin{tabular}{|c|c|c|c|c|c|}
\hline \multicolumn{6}{|c|}{ Coefficients $^{\mathbf{a}}$} \\
\hline \multirow{2}{*}{ Model } & \multicolumn{2}{|c|}{$\begin{array}{l}\text { Unstandardized } \\
\text { Coefficients }\end{array}$} & \multirow{2}{*}{$\begin{array}{c}\text { Stand. } \\
\text { Coeff. } \\
\text { Beta }\end{array}$} & \multirow[t]{2}{*}{$\mathrm{T}$} & \multirow{2}{*}{ Sig. } \\
\hline & $\mathrm{B}$ & Std. Error & & & \\
\hline (Constant) & 549,550 & 112,568 & & 4,882 & 0,0001 \\
\hline Ransum jadi & 12,372 & 1,098 & 0,898 & 11,270 & 0,0001 \\
\hline Pakan jagung & 0,068 & 0,662 & 0,007 & 0,103 & 0,9190 \\
\hline Pakan dedak & 1,138 & 1,420 & 0,064 & 0,801 & 0,4300 \\
\hline a. Dependent $\mathrm{Va}$ & & & & & \\
\hline
\end{tabular}

Sesuai hasil estimasi di atas, diperoleh model regresi linear berganda berikut: $\mathrm{Q}=549,550+12,372$ RsJd + 0,068 PkJgg + 1,138 PkDdk

Untuk memeriksa apakah hasil estimasi ini memenuhi hipotesis penelitian (hipotesis apriori) yang telah dibangun, maka sesuai model regresi linear berganda yang diperoleh, ketiga parameter estimasi masing-masing parameter $b$ untuk variabel ransum jadi, parameter $c$ untuk pakan jagung, dan parameter $d$ untuk pakan dedak menghasilkan tanda yang positif (+). Hal ini menunjukan ketiga variabel memiliki hubungan positif terhadap produksi telur (Q) dimana memenuhi hipotesis yang diberikan.

Hasil estimasi menunjukan bahwa nilai Koefisien Determinasi $\left(\mathrm{R}^{2}\right)$ sebesar 0,868 yang berarti sebesar $86,8 \%$ variasi variabel dependen produksi telur (Q) dapat dijelaskan oleh variasi variabel-variabel independen (ransum jadi, pakan jagung, dan pakan dedak) secara bersama-sama.

Nilai statistik $\mathrm{F}$ yang ditunjukkan oleh nilai probabilitas $F$ adalah sebesar 0,0001. Uji F merupakan uji signifikansi terhadap statistik $\mathrm{R}^{2}$ (Abebe, 2019). Nilai tersebut memiliki arti $\mathrm{R}^{2}$ berbeda nyata dengan nol, artinya variabel independen dalam persamaan secara bersama-sama signifikan mempengaruhi variabel dependen. Sesuai hasil ini maka dapat diterima bahwa variabel-variabel ransum jadi (RsJd), pakan jagung (PkJgg), dan pakan dedak (PkDdk) yang dimasukan dalam persamaan produksi telur secara statistik bersama-sama mempengaruhi produksi telur.

Uji statistik $t$ digunakan untuk melihat apakah masing-masing variabel independen secara individual berpengaruh nyata atau tidak terhadap variabel dependen (Kim, 2015). Hasil uji statistik $t$ menunjukan bahwa nilai probabilitas $t$ untuk variabel ransum jadi (RsJd) adalah sebesar 0,0001 berarti variabel ransum jadi sangat signifikan mempengaruhi produksi telur. Sedangkan nilai probabilitas $t$ untuk variabel pakan jagung (PkJgg) sebesar 0,919 berarti variabel pakan jagung tidak signifikan mempengaruhi produksi telur. Juga nilai probabilitas $t$ untuk variabel pakan dedak (PkDdk) sebesar 0,430 berarti variabel pakan dedak tidak signifikan mempengaruhi produksi telur.

Sesuai hasil uji statistik $t$ di atas hanya pemberian ransum jadi secara statistik mempengaruhi produksi telur. Mungkin hampir tidak dapat diterima bahwa pemberian pakan jagung dan pakan dedak pada perusahaan peternakan ayam petelur UD. Fitra Abadi tidak mempengaruhi produksi telur. Karena umumnya peternak menganggap bahwa jagung dan dedak merupakan dua jenis bahan makanan yang memiliki kandungan nutrisi cukup baik untuk diberikan kepada 
ternak, sehingga apabila diberikan langsung dapat meningkatkan pertumbuhan fisik ternak bahkan juga meningkatkan produksi dari ternak yang bersangkutan.

Afandi et al. (2016) menyatakan pemberian makanan berpengaruh langsung terhadap performa produksi yaitu konsumsi pakan, produksi telur, konversi pakan dan deplesi. Ayam ras petelur yang tercukupi secara nutrisi pakan, akan tumbuh secara optimal dengan produksi telur yang maksimal. Ini berarti, pemenuhan zat gizi pada pakan sangat diperlukan, terutama kandungan protein tercerna, keseimbangan asam amino dan energi metabolisme. Pakan yang bermutu tidak semata-mata ditentukan dari tinggi rendahnya kandungan protein kasar, akan tetapi juga ditentukan dari kelengkapan unsur nutrisi yang lain. Sesuai hal ini, dengan melihat hasil analisis proksimat pakan, sebaiknya peternak ayam ras petelur perlu memperhatikan keseimbangan kandungan nutrisi pakan.

Berdasarkan pendapat Afandi et al. (2016) maka dapat diterima mengapa pemberian pakan jagung dan dedak dalam campuran gabungan dengan ransum jadi (toko), secara statistik tidak signifikan mempengaruhi produksi telur. Diketahui bahwa ransum jadi yang dibeli di toko untuk ayam petelur adalah ransum yang sudah disusun dan disesuaikan kandungan nutrisinya secara lengkap sesuai dengan periode umur dan pertumbuhan ayam petelur. Ransum jadi ini disusun oleh perusahaan pembuatan makanan ternak dan dijamin kualitasnya untuk merangsang produksi telur pada ayam. Sementara pakan jagung dan pakan dedak secara manual merupakan bahan pakan tunggal yang hanya memiliki kandungan gizi tertentu di dalam bahan tersebut. Oleh karena itu jika diberikan secara bersamaan kepada ayam petelur, kandungan nutrisi ransum jadi dapat langsung dicerna dan memenuhi kebutuhan gizi ayam petelur dengan cepat dibandingkan dengan pakan jagung dan dedak.

\section{Nilai Parameter Intersep}

Hasil estimasi menunjukan nilai parameter $a$ adalah sebesar 549,550 artinya jika ransum jadi, pakan jagung, dan pakan dedak tidak diberikan (jumlah pemberian nol) kepada ayam petelur maka jumlah produksi telur yang dapat dihasilkan dari 2100 ekor ayam adalah sebanyak 549,55 butir atau dibulatkan 550 butir. Nilai parameter $a$ ini dapat diinterpretasi sesuai bidang ilmu peternakan. Apabila ternak ayam petelur tidak diberikan makanan ternak atau ransum, maka secara genetik induk ayam petelur pada umur periode produksi puncak masih memiliki kemampuan atau kesanggupan bawaan untuk dapat menghasilkan telur. Telur yang dihasilkan dari kondisi tanpa ransum hanyalah berasal dari kapasitas ayam petelur sebagai input tetap. Nilai parameter $a$ yang yang positif menerangkan kebenaran hipotesis apriori dari ilmu peternakan sebagaimana yang dijelaskan di atas. Sebaliknya jika nilai parameter $a$ adalah negatif maka secara teoritis produksi telur negatif tidak dapat dijelaskan sehingga interpretasi parameter $a$ dapat diabaikan.

Untuk menilai seberapa besar kapasitas input tetap yakni induk ayam petelur dalam menghasilkan telur jika jumlah makanan yang diberikan adalah nol kilogram, maka angka jumlah telur 550 butir yang dihasilkan menjadi penting untuk diperhatikan. Jika dihitung presentase produksi telur 550 butir dari 2100 ekor ayam petelur, jumlah ayam petelur yang bertelur hanya sebanyak 26,19\%. Angka ini termasuk sangat kecil yang menunjukkan kapasitas input tetap yakni ayam petelur adalah sangat rendah ketika berada pada masa puncak bertelur. Artinya perusahaan peternakan UD. Fitra Abadi dengan kapasitas input tetap yang disebut sebagai periode produksi puncak, terbukti kurang memiliki kemampuan dalam menghasilkan telur. Ini memberikan indikasi adanya kelemahan dalam manajemen produksi terkait dengan penggunaan input tetap yang produktif dan efisien.

\section{Pengaruh Pemberian Ransum Jadi}

Manfaat dari pemberian ransum yang lengkap komposisi gizinya (dibeli di toko) sangat mendukung proses pembentukan telur. Ransum jadi yang dibeli di toko memiliki kandungan gizi yang lengkap dengan berbagai zat gizi, vitamin dan mineral yang telah disusun oleh perusahan pembuatan makanan. Dengan demikian pemberian ransum jadi berpeluang besar memberikan kontribusi menghasilkan telur pada setiap pemberian.

Hasil estimasi menunjukan nilai parameter $b$ untuk variabel ransum jadi adalah sebesar 12,372 butir. Angka ini artinya penambahan atau peningkatan ransum jadi sebesar $1 \mathrm{~kg}$ kepada ayam petelur akan meningkatkan produksi telur rata-rata per hari sebanyak 12,372 butir atau dibulatkan 12 butir. Nilai estimasi 12 butir adalah positif yang menunjukkan pertambahan telur dan penambahan telur dapat diterima sebagai akibat pemberian tambahan ransum jadi.

Afandi et al. (2016) menyatakan pakan dengan nutrisi lengkap dapat berpengaruh langsung terhadap performa produksi yakni konsumsi pakan, produksi telur, dan konversi pakan. Ayam ras petelur yang tercukupi secara nutrisi pakan akan tumbuh secara optimal dengan produksi telur yang maksimal karena zat gizi yang tersedia pada pakan dapat dicerna dengan baik, terutama kandungan protein tercerna, keseimbangan asam amino dan energi metabolisme.

\section{Pengaruh Pemberian Pakan Jagung}

Hasil estimasi menunjukan nilai parameter $c$ untuk variabel pakan jagung adalah sebesar 0,068 butir. Angka ini memiliki artinya penambahan atau peningkatan pakan jagung sebanyak $1 \mathrm{~kg}$ kepada ternak ayam petelur akan meningkatkan produksi telur ratarata per hari sebanyak 0,068 butir atau dibulatkan 0 (nol) butir. Nilai estimasi sebesar 0,068 butir adalah 
Heatubun dkk. 2020: Analisis Kapasitas Produksi Telur Ayam....

positif yang menunjukkan pertambahan telur dapat diterima sebagai akibat pemberian tambahan pakan jagung. Namun menjadi pertanyaan mengapa pemberian pakan jagung memberikan penambahan jumlah telur yang mendekati nol butir?

Afandi et al. (2016) menyatakan bahwa nilai kecernaan makanan yang rendah akan berdampak negatif negatif pada performa produksi telur ayam petelur. Parameter kualitas pakan ayam petelur selain ditentukan oleh protein kasar, juga ditentukan oleh bahan kering, kadar abu, serat kasar, lemak kasar dan gross energy (GE) yang dikonversi ke metabolism energy (ME). Pakan jagung yang dberikan oleh peternak kepada ayam petelur pada perusahaan UD. Fitra Abadi bila dibandingkan ransum jadi yang dibeli di toko, memiliki kandungan nutrisi yang lebih rendah. Oleh karena itu pemberian pakan jagung giling besamasama (dicampur) dengan ransum jadi dari toko, secara kualitas ransum jadi lebih mudah diserap dengan kandungan nutrisi lebih lengkap dibanding pakan jagung. Bahan pakan jagung secara individu mengandung komposisi nutrisi yang relatif lebih rendah dibanding ransum jadi dari toko. Karena itu efek pemberian pakan jagung sangat rendah pengaruhnya terhadap produksi telur dalam penelitian ini.

\section{Pengaruh Pemberian Pakan Dedak}

Hasil estimasi menunjukan nilai parameter $d$ untuk variabel pakan dedak adalah sebesar 1,138 butir. Angka ini memiliki arti penambahan atau peningkatan pakan dedak sebanyak $1 \mathrm{~kg}$ kepada ternak ayam petelur akan meningkatkan produksi telur rata-rata per hari sebanyak 1,138 butir atau dibulatkan menjadi 1 (satu) butir. Nilai estimasi sebesar 1,138 butir adalah positif yang menunjukkan pertambahan telur dapat diterima sebagai akibat pemberian tambahan pakan dedak. Tetapi sama dengan pakan jagung, pemberian pakan dedak juga memberikan penambahan jumlah telur yang sangat kecil hanya sebesar satu butir.

Sama halnya dengan pakan jagung, pakan dedak juga secara individu merupakan pakan dengan komposisi nutrisi yang relatif lebih rendah dibanding komposisi nutrisi ransum jadi yang dibeli di toko. Afandi et al. (2016) menyatakan pakan yang disusun dengan nilai kecukupan kebutuhan nutrisi yang rendah memberikan dampak negatif pada performa produksi telur ayam petelur. Pendapat ini mendukung hasil estimasi untuk pakan dedak dimana penambahan pakan dedak hanya memberikan pengaruh sangat kecil terhadap pertambahan produksi telur ayam petelur.

\section{Elastisitas Produksi}

Penerapan konsep elastisitas dalam teori produksi diperoleh berdasarkan aplikasi fungsi produksi. Besarnya nilai elastisitas menyatakan ukuran sensitivitas dari variabel output (dependen variabel) terhadap adanya perubahan pada variabel input (variabel bebas tertentu) dalam suatu fungsi produksi
(Izekor and Alufohai, 2014 ; Du, et al. 2019). Dalam hal ini berlaku bahwa variabel-variabel input lainnya dianggap tetap atau berlaku kondisi yang disebut ceteris paribus. Hasil perhitungan elastisitas produksi telur masing-masing oleh variabel ransum jadi bernilai sebesar 0,6444, oleh variabel pakan jagung sebesar 0,0050, dan oleh variabel pakan dedak sebesar 0,0346.

Nilai elastisitas dari ketiga variabel di atas semuanya lebih kecil dari satu atau bersifat inelastis. Ini menunjukkan satu persen perubahan pada ketiga variabel independen menyebabkan variabel produksi telur (dependen) meningkat lebih kecil dari satu persen. Secara individual, elastisitas dari ransum jadi sebesar 0,6444 yang berarti satu persen kenaikan pemberian ransum jadi menyebabkan kenaikan produksi telur sebesar 0,64 \%. Sedangkan, elastisitas dari pakan jagung sebesar 0,0050 yang berarti satu persen kenaikan dalam pemberian pakan jagung menyebabkan kenaikan produksi telur sebesar $0,005 \%$. Selanjutnya, elastisitas dari pakan dedak sebesar 0,0346 yang berarti satu persen kenaikan pemberian pakan dedak menyebabkan kenaikan produksi telur sebesar $0,03 \%$.

Bila diperbandingkan nilai elastisitas dari ketiga variabel di atas maka elastisitas dari variabel ransum jadi bernilai paling besar. Ini menunjukkan kapasitas dari ransum jadi untuk meningkatkan produksi telur adalah lebih besar dibanding pakan jagung dan dedak. Hal ini sesuai dengan pembahasan sebelumnya bahwa ransum jadi yang dibeli di toko memiliki komposisi nutrisi lebih lengkap dibanding pakan jagung dan pakan dedak sehingga memberikan pengaruh yang lebih besar pada peningkatan produksi telur dari ayam petelur.

Untuk kebutuhkan prediksi ke depan, hasil elastisitas menunjukkan untuk meningkatkan produksi telur dan menjadi indikator keputusan bagi Manajer Peternakan Fitra Abadi adalah meningkatkan jumlah pemberian ransum jadi (toko). Pemberian pakan jagung dan dedak secara teknis tidak dapat memberikan manfaat lebih baik untuk meningkatkan produksi telur.

\section{SIMPULAN DAN REKOMENDASI}

Dari hasil dan pembahasan di atas, beberapa simpulan dan rekomendasi yang diberikan adalah :

1. Kapasitas ayam petelur sebagai input tetap pada U.D. Fitra Abadi masih rendah yaitu produksi hanya 550 butir dari 2100 ekor ayam petelur atau 26,19\%.

2. Pemberian ransum jadi, pakan jagung, dan pakan dedak berhubungan positif dengan produksi telur. Namun secara statistik hanya ransum jadi yang signifikan mempengaruhi produksi telur, sedangkan kedua pakan lainnya tidak signifikan.

3. Nilai elastisitas sebagai kapasitas dari ketiga input yang digunakan lebih kecil dari satu (bersifat inelastis). Namun kapasitas input ransum jadi lebih besar dari pakan jagung dan pakan dedak.

4. Perusahaan perlu mengurangi pemberian pakan jagung dan dedak dan lebih mengu-tamakan 
pemberian penuh ransum jadi untuk memperoleh jumlah produksi yang maksimal.

\section{DAFTAR PUSTAKA}

Abebe, T. H. 2019. The Derivation and Choice of Appropriate Test Statistic (Z, t, F and ChiSquare Test) in Research Methodology. Journal of Mathematics Letters. 5 (3): 33-40.

Afandi, R., H. Budi, dan H. D. Irfan. 2016. Karakteristik Penggunaan Dua Jenis Pakan terhadap Performa Produksi Ayam Ras Petelur di Kabupaten Blitar, Jawa Timur. https://journal.ugm.ac.id/buletinpeternakan/ article/download Supp File/24288/1646. [2/03/2020].

Du. N., Q. Shao, and R. Hu. 2019. Price Elasticity of Production Factors in Beijing's Picking Gardens. Sustainabi-lity Journal. Vol. 11: 116.

Gujarati, D. N., dan D. C. Poter. 2010. Dasar-dasar Ekonometrika. $5^{\text {th }}$ edition. New York: McGraw-Hill.

Izekor, O. B., and G. O. Alufohai. 2014. Production Elasticities, Return to Scale and Allocative
Efficiency in Yam Production in Edo State, Nigeria. Agrosearch. 14(2): 179-190.

Kim, T.K. 2015. t-Test as a Parametric Statistic. Korean Journal of Anesthesiology. 68(6): 540-546.

Latan, H., dan T. Selva. 2013. Analisis Multivariate. Teknik dan Aplikasi Menggunakan Program IBM SPSS 20.0. Bandung: Alfabeta.

Mishra, S. K. 2007. A Brief History of Production Functions. Munich Personal RePEc Archive (MPRA).

Paul, J. 2019. Does Marginal Productivity Mean, Anything in Real Economic Life?. Munich Personal RePEc Archive (MPRA).

Yadaf, P., and C. S. Marwah. 2015. The Concept of Productivity. International Journal of Engineering and Technical Research (IJETR). 3 (5): 192-196.

Supranto. 2001. Statistika, Teori dan Aplikasi. Edisi Keenam, Jilid 2. Jakarta: Erlangga.

Syverson, C. 2011. What Determines Productivity?. Journal of Economic Literature. 49 (2): 326365 .

Available online at journal homepage: http://ojs3.unpatti.ac.id/index.php/agrinimal 